\title{
Scenario analysis of planting density and pre-commercial thinning: will the mixed forest have a chance?
}

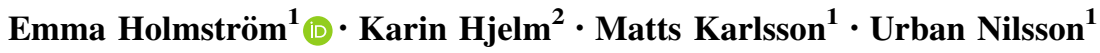

Received: 20 May 2016/Revised: 18 July 2016/Accepted: 20 July 2016/Published online: 2 August 2016

(C) The Author(s) 2016. This article is published with open access at Springerlink.com

\begin{abstract}
In the establishment phase, several management alternatives could be applied that affect the species composition of the future stand. In this study, tree seedling data from experiments with planted Norway spruce (Picea abies L. Karst) and naturally regenerated species, mainly Silver birch (Betula pendula Roth), were used for six simulated pre-commercial thinning (PCT) scenarios. The scenarios included both monocultures and mixed stand alternatives with various initial spacing of the planted Norway spruce $(0,1600$ or 2800 seedlings $)$ and selection of main stems based on relative heights. Further stand development and individual tree growth were simulated until final harvest. Potentially, based on findings of the seedling measurements, the stands could be mixed with five to six species, but the browsing pressure from ungulates reduced this possibility since the height growth for all species except Norway spruce was highly affected by browsing. The simulated mixtures had a small variation between the PCT scenarios for the maximum mean annual increment (about $10 \%)$. Although the growth was similar for Norway
\end{abstract}

Communicated by Dr. Miren del Rio.

Emma Holmström

emma.holmstrom@slu.se

Karin Hjelm

karin.hjelm@skogforsk.se

Matts Karlsson

matts.karlsson@sodra.se

Urban Nilsson

urban.nilsson@slu.se

1 Southern Swedish Forest Research Centre, SLU, Box 49, Alnarp, Sweden

2 Skogforsk, Svalöv, Sweden spruce, the proportion of birch in the final stands differed from 3 to $21 \%$ between treatments and none of the highdensity planting treatments generated a mixed Norway spruce-birch forest at the time of final felling.

Keywords Betula Picea abies - Tending - Mixed forest . Browsing
Abbreviations
MAI $_{\max }$ Maximum mean annual increment $\left(\mathrm{ha}^{-1}\right.$ year $^{-1}$ )
PCT Pre-commercial thinning

\section{Introduction}

Mixed forests may provide more ecosystem services and higher biodiversity than planted monocultures (Felton et al. 2010; Griess and Knoke 2011; Deal et al. 2014). Many private forest owners and companies in Sweden are aiming to combine a high productivity with the promotion of other ecosystem services, and this could be achieved by establishing mixed stands (Agestam et al. 2005). Combining sparse planting with the retention of naturally regenerated seedlings could be a viable management regime for creating such stands.

The tree species that generally dominate natural forest stands on mesic soils in Scandinavia are Norway spruce (Picea abies L. Karst), Scots pine (Pinus sylvestris L) and birch (Betula pendula Roth and Betula pubescens Ehrh) (Götmark et al. 2005; Molinari et al. 2005; Speed et al. 2013). Other species that may be present, but in lower abundancy, include aspen (Populus tremula L), rowan (Sorbus aucuparia L), goat willow (Salix caprea L) and oak (Quercus robur L). However, the Scandinavian forests 
in the boreal- and hemi-boreal zones are seldom natural and are typically dominated by even-aged conifer plantations, mainly Norway spruce in southern Sweden (Bergquist et al. 2011; Nilsson 2013). Regeneration practices that can be applied in commercial forests are governed by forest legislation, policy incentives and management restrictions. These include regulations stipulating the minimum planting densities to secure future yields, which have been a historically important national measure to prevent over-exploitation. Planting densities are generally higher than legislative minima required for regeneration (2000-4000 seedlings on fertile sites in southern Sweden). However, during the last two decades, seedling survival rates in plantations have increased due to improvements in both soil scarification techniques (Johansson et al. 2013) and plant material (Johansson et al. 2007). These trends might lead to a re-evaluation of the recommended planting densities. Instead, target yields and requirements related to species composition in mature stands could provide new scope for applying other regeneration practices. Additionally, in order to qualify for FSC certification, broadleaves should account for at least $10 \%$ of the standing volume of coniferous stands at the time of final harvesting in southern Sweden and $5 \%$ in the north (\$6.3.8 FSC standard) (Swedish FSC Standard for Forest Certification including SLIMF indicators 2010), and the admixture should be the result of active planning and management.

The presence of spontaneously regenerated seedlings could lead to a tenfold increase in stand densities in the regeneration phase (Karlsson and Nilsson 2005). This number could increase further after soil scarification, since soil scarification before planting not only increases survival rates of the planted material but also promotes seedling establishment and facilitates natural regeneration (Karlsson 2001; Clark et al. 2007; Löf and Birkedal 2009). Nevertheless, on average, less than $3 \%$ of the clear-cut areas today are regenerated with a planned combination of sparse planting and natural regeneration (Bergquist et al. 2011), and this number is even lower in the southern parts of Sweden. For a long time, spontaneously regenerated broadleaves were regarded purely as competitors to the planted conifer and therefore treated with herbicides. Nowadays, herbicide treatments on forest land are restricted in Sweden. Therefore, woody species are mostly managed with manual pre-commercial thinning (PCT) using brush saws. The selection during PCT strongly affects the future composition, development and commercial value of the stands (Rytter and Werner 2007; Bataineh et al. 2013).

Natural regeneration of potential canopy tree species could be more of an opportunity than an obstacle in the establishment of mixed stands. When managing Norway spruce-birch mixtures, the challenge is to identify and apply appropriate treatments at appropriate times, i.e., when the species complement each other rather than compete with each other. Mixtures have often been evaluated in terms of either species-specific or total yields (Tham 1994; Valkonen and Valsta 2001; Frivold and Frank 2002; Johansson 2003; Fahlvik et al. 2005; Vila et al. 2007; Piotto 2008; Gamfeldt et al. 2013), or from a unilateral perspective, using birch to facilitate Norway spruce cultivation (Bergqvist 1999; Langvall and Löfvenius 2002), as when one species is used as a nurse tree for other species (Ambrozy 2010).

Early tending, such as various PCT methods, usually show a positive response for the future yield of target tree species (Johansson 1996; Bokalo et al. 2007; Rytter and Werner 2007; Thiffault and Roy 2011; Uotila and Saksa 2014). In general, PCT could also have a long-term impact on the ground vegetation cover since high stocking is a severe limitation due to the reduction in light to the ground and the stocking is more important than the canopy species composition per se. (Hedwall et al. 2013; Bataineh et al. 2014) Similarly, positive response of PCT has been found for small mammals (Homyack et al. 2005; Sullivan et al. 2009).

Several studies have shown that browsing by ungulates strongly influences the tree species composition and structure in mixed stands (Casabon and Pothier 2007; Elie et al. 2009; Speed et al. 2013), mainly because each herbivore has specific foraging preferences (van Beest et al. 2010). For instance, in Scandinavian forests aspen, pine and birch are more attractive to moose (Alces alces) than Norway spruce (Jalkanen 2001; Kullberg and Bergstrom 2001). However, not only specific preferences but also the surrounding landscape matrix will affect the probability of an individual seedling being browsed (Hornberg 2001; Edenius et al. 2002; Bergman et al. 2005). Browsing tends to be more intense in mixed species stands and, unsurprisingly, most severe in stands dominated by mixtures of attractive species (Vehviläinen and Koricheva 2006; Milligan and Koricheva 2013).

To address the needs discussed above, the aim of this study was to evaluate the species composition and growth of mixed stands established within the traditional planting regime. One of the questions was whether there are any possibilities in conventional forestry for creating species mixture by starting with a lower planting density and for implementing active PCT. Could the selection of retained trees in the PCT, based on relative heights between the species, changes the mixture composition in the final stand? This study evaluated the possibilities to retain birch as an additional tree species in the traditional monoculture of Norway spruce, depending on the initial planting density. Furthermore, could these established mixtures fulfill legislative requirements, production goals and current FSC 
standard criteria? By using simulations (from different PCT scenarios up to full rotations) based on results from field experiments in which treatments of soil scarification and planting densities have been applied, this tasks could be fulfilled.

\section{Materials and methods}

\section{Study design}

The pre-commercial thinning (PCT) simulations were carried out using starting values from a mixed species experiment located in Kronoberg County in the south of Sweden. The experiment had a randomized block design with five treatments in each block, and the size of treatment plots was 1 ha. Three of four blocks were located in the Asa experimental forest (lat. $57^{\circ} 10^{\prime} \mathrm{N}$, long. $14^{\circ} 47^{\prime} \mathrm{E}$ ), and one was located in the Tagel experimental forest $\left(57^{\circ} 2^{\prime} \mathrm{N}\right.$, $14^{\circ} 23^{\prime} \mathrm{E}$ ) (Table 1). All blocks were situated on clearcuts of former Norway spruce stands on mesic till soils. Soil scarification and planting were performed the second spring after clear felling in order to create both monoculture treatment plots of planted Norway spruce and mixed treatment plots of planted Norway spruce and naturally regenerated broadleaves. Seedling densities together with seedling heights in sample plots measured after 5 years were used to simulate different PCT. The original planting density treatments were used as a factor with three levels: no planting (plno), low planting density (pllow) (1600 seedlings $\mathrm{ha}^{-1}$ ) and high planting density (plhigh) (2800 seedlings $\mathrm{ha}^{-1}$ ) (see Table 1 for details of the seedling densities before PCT). Block 1 was lacking the no planting treatment, and thereby, in total, data from 19 treatment plots on four blocks were used for the six PCT simulations (Fig. 1).

\section{Measurements}

Seedling densities, heights and damage by browsing were measured in circular sample plots with the radius $1 \mathrm{~m}$, within the treatment plots. The sample plots were laid out in a quadratic grid of $10 \times 10 \mathrm{~m}$ in all treatments and blocks. The center of the sample plots was positioned at the nodes of the quadratic grid, and all plots with less than $3 \mathrm{~m}$ distance to the border of the experiment were excluded from the sampling. Within the sample plots, seedlings of all tree species were specified and counted in height classes of $0.25 \mathrm{~m}$ up to $3.00 \mathrm{~m}$ and thereafter in $0.50 \mathrm{~m}$ classes. The two species of birch were not separated within the height

Table 1 Seedling density (seedlings $\mathrm{ha}^{-1}$ ) for block and treatments, 5 years after establishment and planting

\begin{tabular}{|c|c|c|c|c|c|c|c|c|c|c|c|c|c|}
\hline Block & Treatment & Total & NS PL & NS NR & Birch sp. & Goat willow & Rowan & Pine & Aspen & Oak & Other & $\begin{array}{l}\text { Number } \\
\text { of plots }\end{array}$ & $\begin{array}{l}\text { Number } \\
\text { of empty plots }\end{array}$ \\
\hline \multirow[t]{4}{*}{1} & \multirow[t]{2}{*}{ Plhigh } & 19,000 & 2315 & 413 & 15,006 & 1157 & - & 83 & 83 & - & - & 102 & 36 \\
\hline & & 20,000 & 2110 & 1703 & 14,361 & 1481 & 296 & 185 & - & - & - & 92 & 17 \\
\hline & \multirow[t]{2}{*}{ Pllow } & 17,000 & 1333 & 491 & 14,170 & 1228 & - & - & - & - & - & 101 & 13 \\
\hline & & 6000 & 1302 & 543 & 3653 & 398 & 72 & 36 & 36 & 72 & - & 103 & 48 \\
\hline \multirow[t]{5}{*}{2} & \multirow[t]{2}{*}{ Plhigh } & 5000 & 1772 & 72 & 1266 & 1483 & 36 & 36 & 398 & - & - & 94 & 19 \\
\hline & & 9000 & 2109 & 115 & 3452 & 2800 & 268 & 77 & 38 & - & 38 & 103 & 42 \\
\hline & \multirow[t]{2}{*}{ Pllow } & 19,000 & 1577 & 1885 & 9270 & 6039 & 38 & 154 & 154 & - & - & 98 & 28 \\
\hline & & 10,000 & 1419 & 153 & 7210 & 1151 & 153 & 153 & - & - & 38 & 98 & 34 \\
\hline & Plno & 7000 & - & 133 & 6455 & 177 & 221 & - & 44 & - & - & 87 & 54 \\
\hline \multirow[t]{5}{*}{3} & \multirow[t]{2}{*}{ Plhigh } & 5000 & 2019 & - & 543 & 2562 & 39 & - & - & 39 & - & 100 & 43 \\
\hline & & 7000 & 2122 & - & 1153 & 3137 & 600 & 46 & 46 & 46 & - & 97 & 39 \\
\hline & \multirow[t]{2}{*}{ Pllow } & 4000 & 1460 & 75 & 749 & 1573 & 37 & - & - & - & - & 84 & 22 \\
\hline & & 5000 & 1019 & 42 & 3013 & 594 & 424 & - & 42 & - & - & 90 & 47 \\
\hline & Plno & 1000 & - & 131 & 567 & 305 & - & 44 & - & - & - & 88 & 73 \\
\hline \multirow[t]{5}{*}{4} & \multirow[t]{2}{*}{ Plhigh } & 17,000 & 2122 & - & 12,308 & 265 & - & 371 & 1273 & 212 & 53 & 75 & 16 \\
\hline & & 24,000 & 2213 & 1980 & 17,779 & 1087 & 78 & 660 & 116 & 78 & - & 97 & 10 \\
\hline & \multirow[t]{2}{*}{ Pllow } & 4000 & 1931 & - & 1409 & 52 & 157 & 157 & - & 313 & - & 76 & 25 \\
\hline & & 28,000 & 1613 & 1103 & 22,324 & 806 & 594 & 764 & 127 & 255 & 42 & 74 & 24 \\
\hline & Plno & 18,000 & - & 917 & 12,678 & 647 & 432 & 108 & 2644 & 755 & 216 & 90 & 6 \\
\hline
\end{tabular}

Planting densities: 2800 (Plhigh), 1600 (pllow) seedlings ha ${ }^{-1}$ and no planting (plno). NS PL planted Norway spruce, NS NR naturally regenerated Norway spruce. Sample plots $=3.14 \mathrm{~m}^{2}$ sample plots 


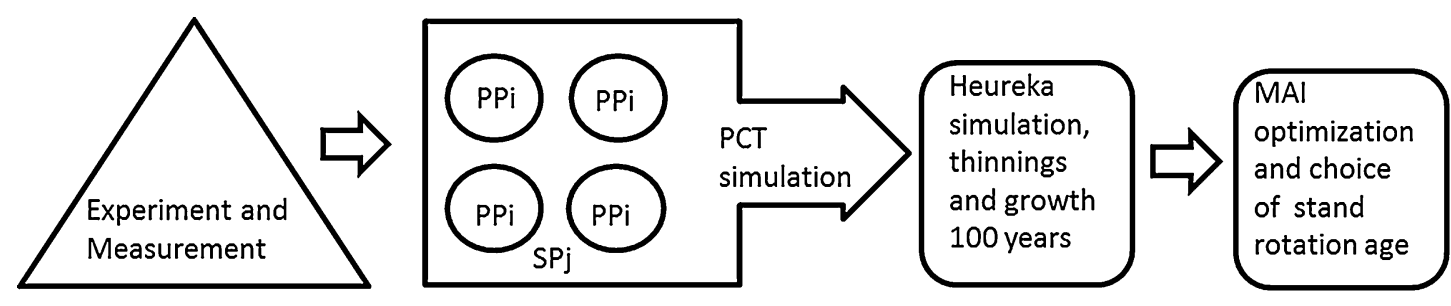

\begin{tabular}{|c|c|c|c|}
\hline $\begin{array}{l}\text { Stand level treatments of } \\
\text { planting and soil } \\
\text { scarification, Sample plot } \\
\text { measurements after } 5 \\
\text { years. }\end{array}$ & $\begin{array}{l}\text { Seedling selections on } \\
\text { both plot and treatment } \\
\text { level, considering } \\
\text { measured height } \\
\text { distributions. }\end{array}$ & $\begin{array}{l}\text { Simulation on } \\
\text { both plot and } \\
\text { treatment level, } \\
\text { basal area and } \\
\text { height } \\
\text { distributions. }\end{array}$ & $\begin{array}{l}\text { Evaluation on } \\
\text { stand level, } \\
\text { volume and mean } \\
\text { annual } \\
\text { increment. }\end{array}$ \\
\hline $\begin{array}{l}19 \text { treatment plots in } 4 \\
\text { blocks, } 2 \text { planting } \\
\text { densities and } 1 \text { control } \\
\text { treatment. }\end{array}$ & $\begin{array}{l}19 \text { treatment plots, } \\
6 \text { PCT simulations: } \\
114 \text { stands }\end{array}$ & $\begin{array}{l}16 \text { planted } \\
\text { treatments, } 5 \text { PCT } \\
\text { simulations: } 80 \\
\text { stands }\end{array}$ & $\begin{array}{l}2 \text { planting } \\
\text { densities, } 5 \text { PCT } \\
\text { simulations: } 80 \\
\text { stands }\end{array}$ \\
\hline
\end{tabular}

Fig. 1 Visualization of the steps in the scenario analysis. Starting with field experiments and measurements, thereafter PCT simulation, Heureka simulation and finally evaluation of stand development.

classes, but the total percentage of each birch species in the plots was recorded. Planted and naturally regenerated Norway spruce seedlings were recorded in separate groups.

\section{Browsing}

Browsing was recorded separately for birch and for other species in the sample plots. The height of the highest birch seedling of good quality was recorded (referred to as the quality height class). The quality requirements for being retained after PCT were absence of double stems, stem crookedness and stem damage $>1 \mathrm{dm}^{2}$. For all other species, browsing damage was recorded in a three-level scale depending on the severity of damage to the leading shoot: (1) undamaged, (2) damaged but replaced with new shoot and (3) severely damaged seedling with shrub-shaped phenology. The proportion of each damage class was recorded per species in each sample plot. The same person did the classification of browsing for all sample plots.

\section{PCT simulations and stand development}

PCT was simulated using the $\mathrm{R} \times 633.00$ software $(\mathrm{R}$ Core Team 2013). Six PCT scenarios were constructed with different criteria for the selection of retained trees, mimicking the selection of the human performer of the PCT (Table 2; Fig. 1). A two-level selection routine was implemented in order to adjust for uneven spatial distribution of seedlings, both regarding frequency and height
$\mathrm{PP}_{i}=$ plot priority index and $\mathrm{SP}_{j}=$ stand priority index. Further details of the figure are explained in the text of "Materials and methods" section

distribution. The priorities were first applied at the sample plot level, where each seedling was assigned a plot priority index $\left(\mathrm{PP}_{i}\right.$ where $i=1 \ldots n$ seedlings in sample plot). Subsequently, all seedlings were prioritized on the 1-ha treatment plot level, resulting in a stand priority index $(S P j$ where $j=1 \ldots N$ seedlings in the treatment plot). The priority was specific for the six PCT scenarios with variations of the criteria for seedling height and species properties. General restriction sets for all simulations were a maximum of three retained seedlings per sample plot and a maximum seedling density on the treatment plots of 2000 seedlings $\mathrm{ha}^{-1}$. Restrictions were also made for the possibility to choose suppressed seedlings regardless of species in order to mimic the traditional behavior of selections in PCT. Suppressed seedlings were defined as seedlings with heights lower than half of the mean height of the three upper quantiles of the seedlings in the treatment plot. In planted treatments, the mean height was only based on planted Norway spruce seedlings, whereas in the unplanted treatments, it was based on all naturally regenerated seedlings. The defined height threshold for a suppressed seedling varied between treatment plots and within blocks, ranging from 0.2 to $1.0 \mathrm{~m}$.

Two of the simulations were monoculture scenarios, Norway spruce (NS) and birch (B) (Table 2). The priority for individual seedlings was first set on plot level where the highest seedling in the sample plot was indexed $\mathrm{PP}_{1}$, second highest seedling $\mathrm{PP}_{2} \ldots \mathrm{PP}_{n}$. Thereafter, on a stand level, the highest seedling of all sample plot seedlings 
Table 2 Summary of PCT simulations, abbreviations and prioritizing criteria

\begin{tabular}{ll}
\hline NS & Keep only spruce, planted and naturally regenerated \\
\hline B & Keep only birch, both species \\
NSBh & Prio spruce for retention if not suppressed + prio the highest birches \\
NSBq & Prio spruce for retention if not suppressed + remove poor quality birches \\
NSBe & Prio spruce for retention if not suppressed + prio birches with heights similar to spruce height \\
MS & Prio to maximize the number of tree species in the stand \\
\hline
\end{tabular}

Prio prioritize
$\left(\mathrm{PP}_{1}\right)$ was indexed $\mathrm{SP}_{1}$, the second highest $\mathrm{SP}_{2}$ until all $\mathrm{PP}_{1}$ was selected, and thereafter, the highest seedling of all $\mathrm{PP}_{2}$, $\mathrm{PP}_{3}$, etc. was selected until 2000 seedlings per hectare were selected.

In three of the scenarios (referred to as NSBh, NSBe and $\mathrm{NSBq}$ respectively), the aim was to retain a mixed species stand of Norway spruce and birch after PCT, NSB scenarios. In these scenarios, Norway spruce had a higher priority to be retained after PCT than the other species on a plot level. The weighting in favor of Norway spruce was done in order to mimic the decision of the forest owner in a real PCT situation, i.e., to keep the planted seedlings as long as they were present and vital. The three scenarios differed in priorities of birch and other broadleaved seedlings: For NSBh, the priority was to retain seedlings based on their maximum height; for NSBe, the priority was to retain seedlings with a height similar to the average height of the planted Norway spruce; and for the third scenario (NSBq), the priority was to exclude seedlings with poor quality by using the recorded quality height class in each sample plot.

In the last scenario (MS-multiple species), the aim was to maximize the number of tree species on the 1-ha plot level. The suppressed seedlings that were removed from the other simulations were included in the possible selection pool. In this scenario, species-specific $\mathrm{PP}_{i}$ was calculated before $\mathrm{SP}_{j}$ was calculated. Therefore, several seedlings per sample plot could be assigned $\mathrm{PP}_{i}=1$ if it contained multiple species, but not more than three seedlings per sample plot could be selected. Future main stems were considered to be all seedlings with heights in the three upper quartiles of the retained seedling cohort after the PCT simulation. The MS scenario was not further simulated into a mature stand, due to the limitations in growth simulations of some of the species. Only the species magnitude after PCT was estimated and compared with the other PCT simulations.

Height distributions after simulated PCT in the 1-ha treatment plots served as starting values for simulations of stand developments in Heureka Planwise (Fig. 1). Only planted treatments were used, and the PCT scenarios analyzed were monocultures (NS and B) and mixtures (NSBh, NSBq, and NSBe). Heureka Planwise is a stand-level management simulation system with a growth and yield simulator, using both tree and stand growth models (Elfving 2010; Fahlvik et al. 2014b; Wikström et al. 2011). Each simulated PCT selection of every treatment became unique stand simulation. Heureka Planwise also includes a treatment program generator and optimizer. The treatment program generator computes a set of thinning and final felling alternatives for each stand unit within frames set by the user (in this case, PCT scenarios). In this simulation, timing of thinnings was tested according to the recommendations for fertile sites (G32) used in practical forestry in southern Sweden. Thinnings were simulated to be done from below, but at first thinning, strip-roads with a thinning quotient of one were simulated. Thereafter, the thinningand final-felling alternative with the highest net-present value (NPV) at $3 \%$ interest rate value was chosen for each stand, i.e., each combination of treatment plot and PCT simulation. Since production will be affected by the timing of final felling, the optimal time for final felling according to NPV was not used in this study. Instead, stand structure was reported at the time of maximum mean annual increment $\left(\mathrm{MAI}_{\max }\right)$, which occurred about 10-20 years after optimal time of final felling according to NPV. The simulations resulted in individual thinning programs for each stand but with the same thinning recommendations and with an attempt to maintain the species proportions set in the initial PCT simulation. In the high planting densities (plhigh), all PCT scenarios in all plots except for PCT in pure birch (scenario B) were thinned at least once and in many stands two thinnings were simulated. In the low planting density (pllow), thinning was done once or twice in the mixed forest (NSBh, NSBe, NSBq), whereas pure Norway spruce $(\mathrm{N})$ was thinned one time in half of the stands and not thinned at all in the others. In the pure birch (B), no thinning was done neither for high planting nor for low planting densities (plhigh or pllow).

Time for final felling was defined as the 5-year period when the mean annual increment (MAI) was maximum $\left(\mathrm{MAI}_{\max }\right)$. The stand structure at this age was used for comparisons of growth parameters between the different planting densities and PCT scenarios (Fig. 1). At this age, number of stems, quadratic mean diameter, standing volume, total volume production including removals in 
thinnings and mean annual increment were calculated for each stand. The means of the variables calculated at the time of final felling were compared with the two planting densities (plhigh and pllow) and the PCT simulations. The abundant species Norway spruce, Scots pine, oak, rowan, goat willow and aspen were treated species-wise in the Heureka simulations, but the two species of birch were treated as one single, pooled species.

\section{Results}

Before the PCT simulations, the overall most abundant species was silver birch with densities between 500 and 17 000 seedlings ha ${ }^{-1}$ in the 1-ha treatment plots (Table 1). All planted treatment plots had a survival of more than $60 \%$ (mean survival rate $82 \%$ ) 5 years after establishment. Only naturally regenerated birch and planted Norway spruce reached a mean height over $1.0 \mathrm{~m}$ after 5 years (median height $1.1 \mathrm{~m}$ for both species) with maximum heights of 4.0 and $3.0 \mathrm{~m}$, respectively (Fig. 2).

The most abundant species besides Norway spruce and birch were aspen, goat willow, oak, pine and rowan (mean height class $0.75,0.75,0.25,0.25,0.75 \mathrm{~m}$, respectively) with no seedlings over the height class $1.75 \mathrm{~m}$ (Fig. 2). Of the additional species, seedlings of the three lower quartiles were below $1.0 \mathrm{~m}$. The mean proportion of damaged seedlings of all additional species was $77 \%$, of which $82 \%$ were classified as severely damaged. In all PCT simulations, the future main stems, defined as remaining trees in the three upper quartiles, were dominated by Norway spruce and birch (Table 3).

The Norway spruce monoculture simulation (NS) generated stem densities of about 1400 and 1900 stems ha $^{-1}$, in pllow and plhigh densities, respectively, with mean heights of 1.5 and $1.4 \mathrm{~m}$ (Table 3). After Heureka
Fig. 2 Frequency of measured seedling heights $(\mathrm{m})$ in sample plots for a Norway spruce; b birch; c all other tree species. The dashed lines are first and third quantile; the solid lines are the median of the frequency
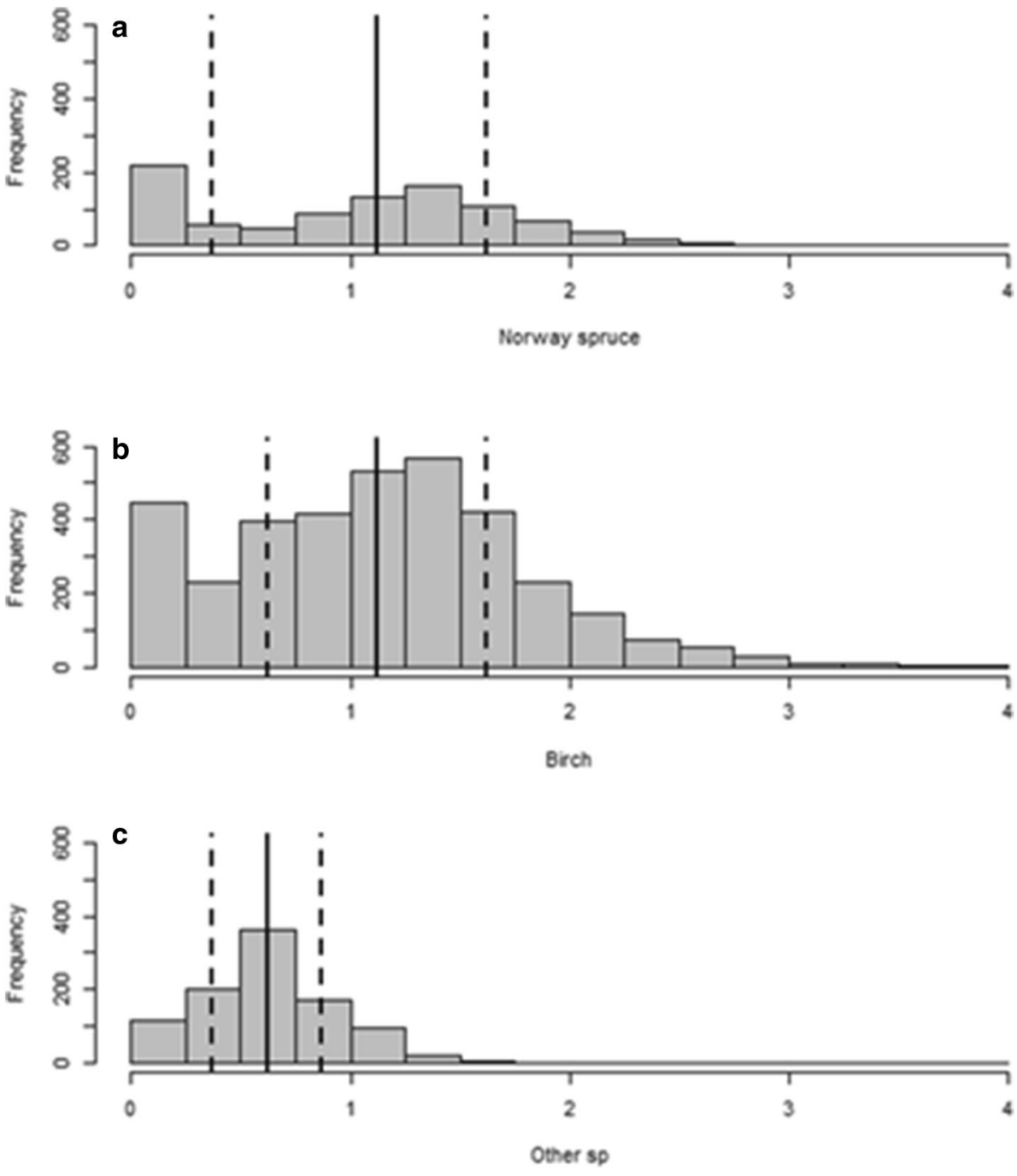

Seedling height $(\mathrm{m})$ 
Table 3 Mean seedlings $\mathrm{ha}^{-1}$ and mean seedling height $(\mathrm{m})$ for species and simulations in the experimental treatments

\begin{tabular}{|c|c|c|c|c|c|c|c|}
\hline & \multicolumn{4}{|c|}{ Mean seedlings ha $^{-1}$} & \multicolumn{3}{|c|}{ Mean seedling height $(\mathrm{m})$} \\
\hline & \multicolumn{4}{|l|}{ Norway } & \multicolumn{3}{|l|}{ Norway } \\
\hline & Spruce & Birch & Other & Total & Spruce & Birch & Other \\
\hline \multicolumn{8}{|l|}{ Plhigh } \\
\hline NS & 1896 & 0 & 0 & 1896 & 1.4 & - & - \\
\hline $\mathrm{NSBh}$ & 1732 & 207 & 214 & 2152 & 1.4 & 2.2 & 1.0 \\
\hline $\mathrm{NSBq}$ & 1737 & 202 & 214 & 2152 & 1.4 & 2.2 & 1.0 \\
\hline NSBe & 1896 & 151 & 78 & 2125 & 1.4 & 1.5 & 1.2 \\
\hline B & 0 & 1608 & 0 & 1608 & - & 1.6 & - \\
\hline MS & 527 & 493 & 1174 & 2193 & 1.8 & 2.1 & 0.5 \\
\hline \multicolumn{8}{|l|}{ Pllow } \\
\hline NS & 1358 & 0 & 0 & 1358 & 1.5 & - & - \\
\hline NSBh & 1329 & 568 & 209 & 2106 & 1.5 & 1.8 & 0.9 \\
\hline NSBq & 1329 & 553 & 199 & 2081 & 1.5 & 1.8 & 0.9 \\
\hline NSBe & 1358 & 569 & 283 & 2210 & 1.5 & 1.6 & 1.0 \\
\hline B & 0 & 1749 & 0 & 1749 & - & 1.5 & - \\
\hline MS & 588 & 572 & 1123 & 2283 & 1.8 & 2.0 & 0.6 \\
\hline \multicolumn{8}{|l|}{ Plno } \\
\hline NS & 54 & 0 & 0 & 54 & 0.6 & - & - \\
\hline NSBh & 54 & 0 & 220 & 1627 & 0.6 & 1.4 & 0.8 \\
\hline $\mathrm{NSBq}$ & 54 & 1354 & 220 & 1627 & 0.6 & 1.4 & 0.8 \\
\hline NSBe & 54 & 1398 & 218 & 1670 & 0.6 & 1.0 & 0.8 \\
\hline B & 0 & 1503 & 0 & 1503 & - & 1.3 & - \\
\hline MS & 196 & 689 & 1155 & 2039 & 0.2 & 1.7 & 0.7 \\
\hline
\end{tabular}

For meanings of abbreviations, see legends of Tables 1 and 2

simulations, the maximum mean annual increment $\left(\mathrm{MAI}_{\max }\right)$ of the stand was lower in the former $\left(10.7 \mathrm{~m}^{3} \mathrm{ha}^{-1}\right.$ year $\left.^{-1}\right)$ than in the latter $\left(11.6 \mathrm{~m}^{3} \mathrm{ha}^{-1}\right.$ year $^{-1}$ ) (Table 4; Fig. 2).

In the simulated PCTs of Norway spruce and birch mixtures (NSBh, NSBq and NSBe), the densities of Norway spruce ranged between 1732-1896 (plhigh) and 1329-1358 (pllow) seedlings ha ${ }^{-1}$ (Table 3) and the mean birch densities was $10 \%$ in plhigh treatments and $30 \%$ in pllow regardless of height selections of birch in PCT simulations. The mean heights of retained birch seedlings were the same for NSBh and NSBq in both planting densities (Table 3), but for NSBe, they were 0.7 and $0.2 \mathrm{~m}$ smaller for the plhigh and pllow, respectively. For the plhigh treatments, the small proportions of birch did not affect mean values of rotation length ( \pm 1 year), total volume (at most $\left.-17 \mathrm{~m}^{3} \mathrm{ha}^{-1}\right)$ or $\mathrm{MAI}_{\max }\left(0-0.3 \mathrm{~m}^{3} \mathrm{ha}^{-1}\right.$ year ${ }^{-1}$ ). Birch accounted for $2-5 \%$ of total standing volume at the time of $\mathrm{MAI}_{\max }$.

In stands with low planting densities (pllow), the rotation length and total volume were lower in all mixtures (NSBh, NSBe, NSBq) compared to NS monoculture. This was not true for $\mathrm{MAI}_{\max }$, which was similar for all PCT scenarios. Within the mixtures, there was very low difference between the three means of the NSB simulations. In all NSB simulations, the mean proportion of birch volume in final felling was between 18 and $21 \%$ at the time of MAI $_{\max }$.

In the pure birch simulation (B), it was not possible to meet the goal of 2000 stems ha $^{-1}$ after simulated PCT due to the spatial restrictions in the PCT simulation. $\mathrm{MAI}_{\max }$ was $22-23 \%$ lower, and $\mathrm{MAI}_{\max }$ was reached 19 years sooner than in the NSBh simulation. There were low differences in stem density, mean diameter and total volume production for the stands of the two planting densities in the birch monoculture simulations at the time of final felling.

\section{Discussion}

Establishment of mixed species forests is a possible option for those who want to combine different objectives, as a part of a management strategy to meet FSC standards for example, and for production of supplementary hardwood assortments. Our results indicate that the proportion of birch, by volume, in stands planted at traditional densities will fall below the FSC standard requirement by the end of the rotation period (at a stand age between 60 and 80 years (Table 4). In this study, the retained seedlings were spatially evenly distributed for the species, but a species mixture in groups or clusters are also alternative measures which probably would have given a different species composition in the future stand. However, the additional parameter of mixture resolution was not simulated for in this study.

The results from this study show that, with an active management strategy in an early stage, there are possibilities to create mixed stands. Two of the simulations of stand development with the lower initial planting density (1600 stems $\mathrm{ha}^{-1}$ ) did result in a Norway spruce-birch mixture (Tables 3, 4). However, the results demonstrate the need to apply an active management strategy in order to create a mature mixed forest. One possible strategy could be involving sparse planting of Norway spruce and natural regeneration of birch. Another, less attractive, could be to perform PCT in which also planted seedlings could be removed in favor of naturally regenerated tree species.

However, in this study, priorities in the Norway sprucebirch simulations were set to mimic the decisions of landowners, who are unlikely to ignore investments already made in planted seedlings when conducting PCT. Planted, undamaged and vital seedlings were therefore never removed in favor of naturally regenerated seedlings of other tree species. At all sites, the survival and growth rates 
Table 4 Stand data after Heureka simulations and progression; mean values at time of $\mathrm{MAI}_{\max }$ of the PCT simulations for stands with high and low planting densities (Plhigh and Pllow, respectively)

\begin{tabular}{|c|c|c|c|c|c|c|c|c|c|c|c|c|}
\hline \multirow[t]{3}{*}{ PCT } & \multicolumn{8}{|l|}{ Final felling } & \multirow{2}{*}{\multicolumn{3}{|c|}{$\frac{\text { Total volume production }}{\text { Volume }\left(\mathrm{m}^{3} \mathrm{ha}^{-1}\right)}$}} & \multirow[t]{3}{*}{$\mathrm{MAI}_{\max }$} \\
\hline & \multirow[t]{2}{*}{ Age (years) } & \multicolumn{2}{|c|}{ Stems ha ${ }^{-1}$} & \multicolumn{2}{|c|}{ Diameter $(\mathrm{cm})$} & \multicolumn{3}{|c|}{ Volume $\left(\mathrm{m}^{3} \mathrm{ha}^{-1}\right)(\%)$} & & & & \\
\hline & & Spruce & Birch & Spruce & Birch & Spruce & Birch & Birch & Spruce & Birch & Total & \\
\hline \multicolumn{13}{|c|}{ High density plantations } \\
\hline NS & 70 & 913 & 0 & 28.8 & - & 736 & 0 & 0 & 814 & 0 & 814 & 11.6 \\
\hline NSBh & 71 & 872 & 82 & 28.2 & 24.6 & 676 & 37 & 5 & 742 & 45 & 800 & 11.3 \\
\hline NSBq & 71 & 872 & 78 & 28.3 & 22.5 & 679 & 35 & 5 & 745 & 42 & 801 & 11.3 \\
\hline NSBe & 69 & 882 & 34 & 28.5 & 20.0 & 690 & 17 & 3 & 771 & 22 & 797 & 11.6 \\
\hline B & 52 & 147 & 1120 & 21.0 & 20.4 & 60 & 360 & 87 & 72 & 376 & 452 & 8.7 \\
\hline \multicolumn{13}{|c|}{ Low density plantations } \\
\hline NS & 75 & 868 & 0 & 29.8 & - & 772 & 0 & 0 & 803 & 0 & 803 & 10.7 \\
\hline NSBh & 69 & 566 & 209 & 29.5 & 28.2 & 469 & 125 & 21 & 532 & 165 & 714 & 10.3 \\
\hline NSBq & 69 & 574 & 206 & 29.4 & 28.1 & 476 & 123 & 20 & 537 & 160 & 717 & 10.3 \\
\hline NSBe & 70 & 627 & 187 & 29.1 & 26.5 & 523 & 108 & 18 & 577 & 139 & 733 & 10.5 \\
\hline B & 51 & 0 & 1178 & - & 20.2 & 0 & 399 & 100 & 0 & 399 & 399 & 7.9 \\
\hline
\end{tabular}

Stems ha ${ }^{-1}$ and diameter breast height $(\mathrm{cm})$, standing volume $\left(\mathrm{m}^{3} \mathrm{ha}^{-1}\right)$ and birch percentage $(\%)$. Total volume production for Norway spruce and birch $\left(\mathrm{m}^{3} \mathrm{ha}^{-1}\right)$ and $\mathrm{MAI}_{\max }$, maximum Mean Annual Increment $\left(\mathrm{m}^{3} \mathrm{ha}^{-1}\right.$ year $\left.{ }^{-1}\right)$ of the stand. For other meanings of other abbreviations see legends of Tables 1,2 and 3

of the planted seedlings were sufficient enough to obtain dense monoculture plantations (Table 1).

Modeling mixed forest development, using models based on empirical data, could provide reasonable predictions within the limits of available data (Porte and Bartelink 2002). The Heureka software system is based on data gathered from conifer-dominated stands with similar management as of this experiment and does cover the geographical locations and site productivity (Wikström et al. 2011). The growth functions in Heureka are validated with data from both field experiments and permanent sample plots from the Swedish national forest inventory, covering residual analysis of site index, broadleaved admixture and stand age (Fahlvik et al. 2014a). The stand development for treatment plots with an initially high density of planted Norway spruce was similar in the Heureka runs, regardless of the simulated PCT. The parameters for treatment plots with low planting density (pllow) had higher variance, even in the Norway spruce monoculture simulation (as illustrated by the $\mathrm{MAI}_{\max }$ box plot, Fig. 3). Similar results have been obtained in other studies, both experimental and simulation-based, of birch and Norway spruce mixtures: Comparisons of mixtures and Norway spruce monocultures depend on stand age and stand rotation length since the species differs in growth rhythm (Fahlvik et al. 2011), but a slight yield decrease could not be refuted (Frivold and Frank 2002; Agestam et al. 2005). Accordingly, at the stem densities in our study, the proportion of Norway spruce was not linearly correlated with total stem volume production. These findings are consistent with results of similar simulations involving stands under Scandinavian conditions (Valkonen and Valsta 2001; Fahlvik et al. 2005). We used stand-based $\mathrm{MAI}_{\text {max }}$ to create the comparison between scenarios, but other optimization variables or management criteria might have shifted the stand dynamics and also the species mixture in the final stand. Shorter rotation could have increased the proportion of birch and other broadleaves at the end of the rotation. However, there are negative implications of shortened stand rotations beside the production losses, such as fewer large trees, lower amount of coarse woody debris, decrease in keystone forest vegetation species (Hedwall et al. 2013) and loss in the organic stock (Zanchi et al. 2014).

Relative heights of birch and Norway spruce seedlings influence stand development, at least until first commercial thinning (Fahlvik et al. 2005). The PCT simulations NSBh and NSBe were mimicking two different selection approaches of the birch seedlings due to heights. However, the range of seedling height options available was narrow. In none of the PCT simulations, the mean height of birch was not more or less than $1 \mathrm{~m}$ compared to the Norway spruce heights, mainly due to the small number of tall birch seedlings in the measured data. The fast growth success of the Norway spruce was one explanation and probably browsing damage on the birch seedlings another. 


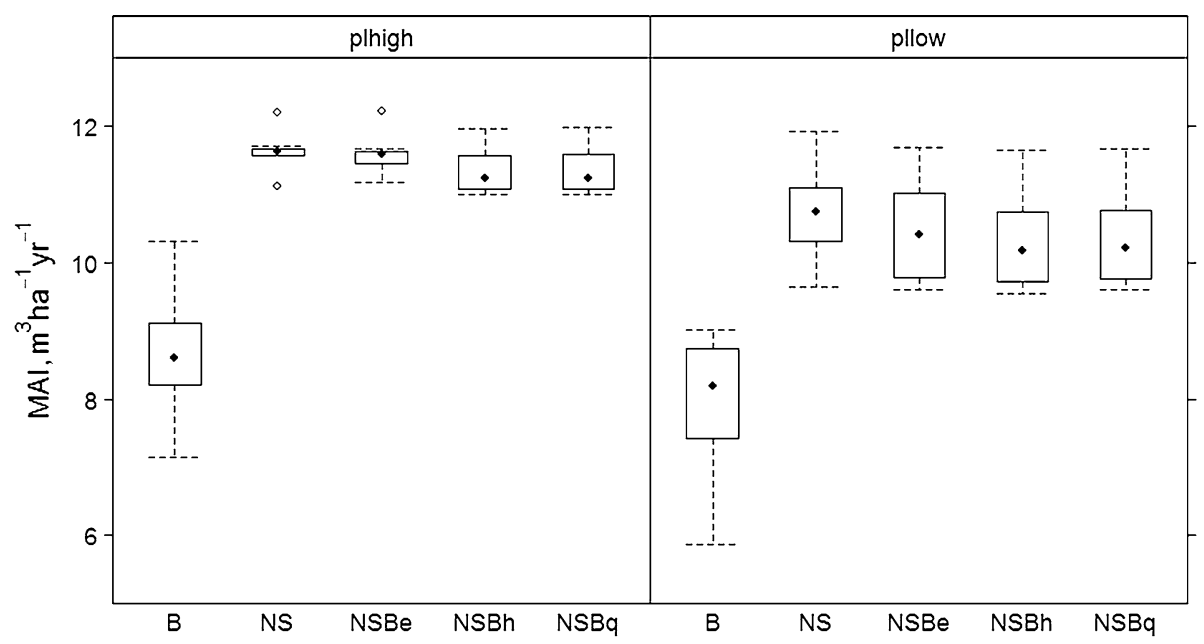

Fig. 3 Box plot of MAImax (maximum mean annual increment, $\mathrm{ha}^{-1}$ year $^{-1}$ ) in the simulations for birch monocultures (B), Norway spruce monocultures (NS), and spruce-birch mixtures (NSB) with high and low planting densities (plhigh and pllow, respectively). For meanings of abbreviations, see legends of Tables 1, 2 and 3. Black

Browsing damage strongly influenced the establishment and structure of the future stands in our simulations, indicating that browsing of naturally regenerated species limits the opportunities to utilize them for alternative PCT approaches. Browsing caused severe reductions, not only in the species' mean heights but more importantly also reductions in the height of potential main stems. This is consistent with other studies (Bergquist et al. 2009). Browsers prefer the fastest growing individuals (Kullberg and Bergstrom 2001), which makes browsing even more important for future tree species composition. In addition, browsing affects stem quality. Increases in frequencies of double stems due to ungulate browsing following similar treatments have been observed in other studies (Bergquist et al. 2009).

The only species that we found regenerated abundantly or in clusters in our experiments were birch and Norway spruce. Our data cannot fully explain the sparse regeneration frequency of the other species; however, there are previous indications that low abundance of a species increases the likelihood that it will be selectively browsed by ungulates (Edenius et al. 2002). We also suspect that lethal browsing may be an important factor, but it was not possible to record mortality of naturally regenerated seedlings 5 years after establishment. The proportion of living seedlings that were browsed is also underestimated in this study since only browsing that resulted in severe changes in morphology, such as double stem, was recorded. Thus, older browsing on branches was not always detected. Low seed tree abundance and adverse germination conditions could also contribute to the low abundance of seedlings of other species. dots indicate median, the border of the box indicates the first and third quartile, length of whiskers represents approximately 2 standard deviations of the data, and the unfilled dots indicate outliers of the whiskers

The combination of several adverse factors, such as low abundance of seed trees, competition from field vegetation on the clearcut, selective browsing on the most rapidly growing seedlings and high browsing pressure, might collectively reduce the tree species diversity in the forest landscape. If this prevails, the forests of southern Sweden are likely to become less diverse with respect to tree species than at the present state (Drössler 2010). Increase in ungulate populations promoted by anthropogenic factors in combination with forest management driving changes in species abundance and diversity is a general trend from several regions (Beguin et al. 2010; Edenius et al. 2011; Chollet et al. 2013).

In conclusion, seedlings of common Swedish tree species, and thus mixed stands, can be obtained by applying traditional regeneration methods. However, regardless of the establishment method applied, heavy browsing by ungulates, as implied of the damage measures, affects the natural regeneration and reduces the competitiveness of all native tree species except Norway spruce.

Acknowledgments We would like to thank Ulf Johansson and the staff at Asa and Tönnersjöhedens experimental stations, SLU. This paper has been written as part of the interdisciplinary program Future Forests financed by Mistra (The Foundation for Strategic Environmental Research), the Forestry Research Institute of Sweden (Skogforsk), the Swedish University of Agricultural Sciences (SLU), and Umeå University.

\section{Compliance with ethical standards}

Conflict of interest The authors declare no conflict of interest. The founding sponsors had no role in the design of the study; in the 
collection, analyses, or interpretation of data; in the writing of the manuscript; and in the decision to publish the results.

Open Access This article is distributed under the terms of the Creative Commons Attribution 4.0 International License (http://creative commons.org/licenses/by/4.0/), which permits unrestricted use, distribution, and reproduction in any medium, provided you give appropriate credit to the original author(s) and the source, provide a link to the Creative Commons license, and indicate if changes were made.

\section{References}

Agestam E, Karlsson M, Nilsson U (2005) Mixed forests as a part of sustainable forestry in southern Sweden. J Sustain For 21:101-117

Ambrozy S (2010) Annual dynamics of natural regeneration of silver birch (Betula pendula Roth) on a research plot located in the area of forest decline in the Silesian Beskid Mountains. Fol For Pol Ser A For 52:76-82

Bataineh MM, Wagner RG, Weiskittel AR (2013) Long-term response of spruce-fir stands to herbicide and precommercial thinning: observed and projected growth, yield, and financial returns in central Maine, USA. Can J For Res 43:385-395. doi:10.1139/cjfr-2012-0343

Bataineh MM, Wagner RG, Olson MG, Olson EK (2014) Midrotation response of ground vegetation to herbicide and precommercial thinning in the Acadian Forest of Maine, USA. For Ecol Manag 313:132-143. doi:10.1016/j.foreco.2013.11.007

Beguin J, Pothier D, Côté SD (2010) Deer browsing and soil disturbance induce cascading effects on plant communities: a multilevel path analysis. Ecol Appl 21:439-451. doi:10.1890/092100.1

Bergman M, Iason GR, Hester AJ (2005) Feeding patterns by roe deer and rabbits on pine, willow and birch in relation to spatial arrangement. Oikos 109:513-520. doi:10.1111/j.0030-1299. 2005.13794.x

Bergquist J, Löf M, Orlander G (2009) Effects of roe deer browsing and site preparation on performance of planted broadleaved and conifer seedlings when using temporary fences. Scand J For Res 24:308-317. doi:10.1080/02827580903117420

Bergquist J, Eriksson A, Fries C (2011) Skogsstyrelsen Polytax 5/7 återväxttaxering: Resultat från 1999-2009. Report from the Swedish Forest Agency. (In Swedish)

Bergqvist G (1999) Wood volume yield and stand structure in Norway spruce understorey depending on birch shelterwood density. For Ecol Manag 122:221-229. doi:10.1016/S03781127(99)00008-0

Bokalo M, Comeau PG, Titus SJ (2007) Early development of tended mixtures of aspen and spruce in western Canadian boreal forests. For Ecol Manag 242:175-184. doi:10.1016/j.foreco.2007.01.038

Casabon C, Pothier D (2007) Browsing of tree regeneration by whitetailed deer in large clearcuts on Anticosti Island, Quebec. For Ecol Manag 253:112-119. doi:10.1016/j.foreco.2007.07.009

Chollet S, Baltzinger C, Ostermann L, Saint-Andre F, Martin JL (2013) Importance for forest plant communities of refuges protecting from deer browsing. For Ecol Manag 289:470-477. doi:10.1016/j.foreco.2012.10.043

Clark CJ, Poulsen JR, Levey DJ, Osenberg CW (2007) Are plant populations seed limited? a critique and meta-analysis of seed addition experiments. Am Nat 170:128-142

Deal RL, Hennon P, O'Hanlon R, D'Amore D (2014) Lessons from native spruce forests in Alaska: managing Sitka spruce plantations worldwide to benefit biodiversity and ecosystem services. Forestry 87:193-208. doi:10.1093/forestry/cpt055
Drössler L (2010) Tree species mixtures-a common feature of southern Swedish forests. Forestry 83:433-441. doi:10.1093/ forestry/cpq 025

Edenius L, Ericsson G, Naslund P (2002) Selectivity by moose vs the spatial distribution of aspen: a natural experiment. Ecography 25:289-294. doi:10.1034/j.1600-0587.2002.250305.x

Edenius L, Ericsson G, Kempe G, Bergström R, Danell K (2011) The effects of changing land use and browsing on aspen abundance and regeneration: a 50-year perspective from Sweden. J Appl Ecol 48:301-309. doi:10.1111/j.1365-2664.2010.01923.x

Elfving B (2010) Growth modelling in the Heureka system. Swedish University of Agricultural Sciences, Faculty of Forestry. http:// heurekaslu.org/wiki/Heureka_prognossystem_\%28Elfving_rap portutkast\%29.pdf. Cited 12 Feb 2015

Elie JG, Ruel JC, Lussier JM (2009) Effect of browsing, seedbed, and competition on the development of yellow birch seedlings in high-graded stands. North J Appl For 26:99-105

Fahlvik N, Agestam E, Nilsson U, Nystrom K (2005) Simulating the influence of initial stand structure on the development of young mixtures of Norway spruce and birch. For Ecol Manag 213:297-311. doi:10.1016/j.foreco.2005.03.021

Fahlvik N, Agestam E, Ekö PM, Linden M (2011) Development of single-storied mixtures of Norway spruce and birch in Southern Sweden. Scand J For Res 26:36-45. doi:10.1080/02827581. 2011.564388

Fahlvik N, Elfving B, Wikström P (2014a) Evaluation of growth models used in the Swedish Forest Planning System Heureka. Silva Fenn 48:1-17

Fahlvik N, Elfving B, Wikström P, Fahlvik N, Elfving B, Wikström P (2014b) Evaluation of growth functions used in the Swedish Forest Planning System Heureka. Silva Fenn. doi:10.14214/sf. 1013

Felton A, Lindbladh M, Brunet J, Fritz Ö (2010) Replacing coniferous monocultures with mixed-species production stands: an assessment of the potential benefits for forest biodiversity in northern Europe. For Ecol Manag 260:939-947. doi:10.1016/j.foreco. 2010.06.011

Frivold LH, Frank J (2002) Growth of mixed birch-coniferous stands in relation to pure coniferous stands at similar sites in southeastern Norway. Scand J For Res 17:139-149

Gamfeldt L et al (2013) Higher levels of multiple ecosystem services are found in forests with more tree species. Nat Commun 4:1340. doi:http://www.nature.com/ncomms/journal/v4/n1/suppinfo/ ncomms2328_S1.html

Götmark F, Fridman J, Kempe G, Norden B (2005) Broadleaved tree species in conifer-dominated forestry: regeneration and limitation of saplings in southern Sweden. For Ecol Manag 214:142-157. doi:10.1016/j.foreco.2005.04.001

Griess VC, Knoke T (2011) Growth performance, windthrow, and insects: meta-analyses of parameters influencing performance of mixed-species stands in boreal and northern temperate biomes. Can J For Res 41:1141-1159. doi:10.1139/x11-042

Hedwall P-O, Brunet J, Nordin A, Bergh J (2013) Changes in the abundance of keystone forest floor species in response to changes of forest structure. J Veg Sci 24:296-306. doi:10.1111/j. 1654-1103.2012.01457.x

Homyack JA, Harrison DJ, Krohn WB, Homyack JA, Harrison DJ, Krohn WB (2005) Long-term effects of precommercial thinning on small mammals in northern Maine. For Ecol Manag 205:43-57. doi:10.1016/j.foreco.2004.10.005

Hornberg S (2001) The relationship between moose (Alces alces) browsing utilisation and the occurrence of different forage species in Sweden. For Ecol Manag 149:91-102. doi:10.1016/ s0378-1127(00)00547-8

Jalkanen A (2001) The probability of moose damage at the stand level in southern Finland. Silva Fenn 35:159-168 
Johansson T (1996) Management of birch forest. Nor J Agric Sci 24:7-20

Johansson T (2003) Mixed stands in Nordic countries-a challenge for the future. Biomass Bioenergy 24:365-372. doi:10.1016/ s0961-9534(02)00165-4

Johansson K, Nilsson U, Allen HL (2007) Interactions between soil scarification and Norway spruce seedling types. New For 33:13-27. doi:10.1007/s11056-006-9010-y

Johansson K, Nilsson U, Örlander G (2013) A comparison of longterm effects of scarification methods on the establishment of Norway spruce. Forestry 86:91-98. doi:10.1093/forestry/cps062

Karlsson M (2001) Natural regeneration of broadleaved tree species in southern Sweden - effects of silvicultural treatments and seed dispersal from surrounding stands. Dissertation, Swedish University of Agricultural Sciences

Karlsson M, Nilsson U (2005) The effects of scarification and shelterwood treatments on naturally regenerated seedlings in southern Sweden. For Ecol Manag 205:183-197. doi:10.1016/j. foreco.2004.10.046

Kullberg Y, Bergstrom R (2001) Winter browsing by large herbivores on planted deciduous seedlings in southern Sweden. Scand J For Res 16:371-378. doi:10.1080/02827580152496768

Langvall O, Löfvenius MO (2002) Effect of shelterwood density on nocturnal near-ground temperature, frost injury risk and budburst date of Norway spruce. For Ecol Manag 168:149-161. doi:10. 1016/S0378-1127(01)00754-X

Löf M, Birkedal M (2009) Direct seeding of Quercus robur L. for reforestation: the influence of mechanical site preparation and sowing date on early growth of seedlings. For Ecol Manag 258:704-711. doi:10.1016/j.foreco.2009.05.008

Milligan HT, Koricheva J (2013) Effects of tree species richness and composition on moose winter browsing damage and foraging selectivity: an experimental study. J Anim Ecol 82:739-748. doi:10.1111/1365-2656.12049

Molinari C, Bradshaw RHW, Risbøl O, Lie M, Ohlson M (2005) Long-term vegetational history of a Picea abies stand in southeastern Norway: implications for the conservation of biological values. Biol Conserv 126:155-165. doi:10.1016/j.biocon.2005. 05.007

Nilsson P (2013) Skogsdata: aktuella uppgifter om de svenska skogarna från Riksskogstaxeringen. 2013, Tema: Olika mått på skogens ålder och trädslagssammansättning. Institutionen för skoglig resurshushållning, Sveriges lantbruksuniversitet, Umeå

Piotto D (2008) A meta-analysis comparing tree growth in monocultures and mixed plantations. For Ecol Manag 255:781-786. doi:10.1016/j.foreco.2007.09.065

Porte A, Bartelink HH (2002) Modelling mixed forest growth: a review of models for forest management. Ecol Model 150:141-188. doi:10.1016/s0304-3800(01)00476-8
R Core Team (2013) R: a language and environment for statistical computing. R Foundation for Statistical Computing, Vienna

Rytter L, Werner M (2007) Influence of early thinning in broadleaved stands on development of remaining stems. Scand J For Res 22:198-210. doi:10.1080/02827580701233494

Speed JDM, Austrheim G, Hester AJ, Solberg EJ, Tremblay JP (2013) Regional-scale alteration of clear-cut forest regeneration caused by moose browsing. For Ecol Manag 289:289-299. doi:10.1016/ j.foreco.2012.10.051

Sullivan TP, Sullivan DS, Lindgren PMF, Ransome DB (2009) Stand structure and the abundance and diversity of plants and small mammals in natural and intensively managed forests. For Ecol Manag 258:S127-S141. doi:10.1016/j.foreco.2009.06.001

Swedish FSC (2010) Standard for forest certification including SLIMF indicators. FSC

Tham A (1994) Crop plans and yield predictions for Norway spruce (Picea abies (L.) Karst.) and birch (Betula pendula Roth and Betula pubescens Ehrh.) mixtures. Stud For Suec 195:1-21

Thiffault N, Roy V (2011) Living without herbicides in Quebec (Canada): historical context, current strategy, research and challenges in forest vegetation management. Eur J For Res 130:117-133. doi:10.1007/s10342-010-0373-4

Uotila K, Saksa T (2014) Effects of early cleaning on young Picea abies stands. Scand J For Res 29:111-119. doi:10.1080/ 02827581.2013 .869349

Valkonen S, Valsta L (2001) Productivity and economics of mixed twostoried spruce and birch stands in Southern Finland simulated with empirical models. For Ecol Manag 140:133-149. doi:10.1016/ s0378-1127(00)00321-2

van Beest FM, Mysterud A, Loe LE, Milner JM (2010) Forage quantity, quality and depletion as scale-dependent mechanisms driving habitat selection of a large browsing herbivore. J Anim Ecol 79:910-922. doi:10.1111/j.1365-2656.2010.01701.x

Vehviläinen H, Koricheva J (2006) Moose and vole browsing patterns in experimentally assembled pure and mixed forest stands. Ecography 29:497-506

Vila M, Vayreda J, Comas L, Josep Ibanez J, Mata T, Obon B (2007) Species richness and wood production: a positive association in Mediterranean forests. Ecol Lett 10:241-250. doi:10.1111/j. 1461-0248.2007.01016.x

Wikström P et al (2011) The Heureka forestry decision support system: an overview. Math Comput For Nat Resour Sci 3:87-94

Zanchi G, Belyazid S, Akselsson C, Yu L (2014) Modelling the effects of management intensification on multiple forest services: a Swedish case study. Ecol Model 284:48-59. doi:10. 1016/j.ecolmodel.2014.04.006 